\title{
Bioequivalence assessment of two formulations of ibuprofen
}

This article was published in the following Dove Press journal:

Drug Design, Development and Therapy

18 October 201।

Number of times this article has been viewed

\author{
Zeyad A Al-Talla' \\ Sabah H Akrawi \\ Luke T Tolley ${ }^{3}$ \\ Salim H Sioud' \\ Mohammed F Zaater ${ }^{4}$ \\ Abdul-Hamid M Emwas' \\ 'Analytical and NMR Core \\ Laboratories, King Abdullah University \\ of Science and Technology, Thuwal, \\ Kingdom of Saudia Arabia; ${ }^{2}$ College \\ of Pharmacy, Al-Ain University, Al-Ain, \\ United Arab Emirates; ${ }^{3}$ Department \\ of Chemistry and Biochemistry, \\ Southern Illinois University \\ Carbondale, Carbondale, IL, USA; \\ ${ }^{4}$ Department of Chemistry, Jordan \\ University of Science and Technology, \\ Jordan University of Science and \\ Technology, Irbid, Jordan
}

Correspondence: Zeyad A Al-Talla

Analytical Core Laboratory, King Abdullah

University of Science and Technology,

Thuwal, 23955-6900,

Kingdom of Saudi Arabia

Tel +96628084323

Email zeyad.talla@kaust.edu.sa
Background: This study assessed the relative bioavailability of two formulations of ibuprofen. The first formulation was Doloraz ${ }^{\circledR}$, produced by Al-Razi Pharmaceutical Company, Amman, Jordan. The second forumulation was Brufen ${ }^{\circledR}$, manufactured by Boots Company, Nottingham, UK.

Methods and results: A prestudy validation of ibuprofen demonstrated long-term stability, freeze-thaw stability, precision, and accuracy. Twenty-four healthy volunteers were enrolled in this study. After overnight fasting, the two formulations (test and reference) of ibuprofen (100 mg ibuprofen $/ 5 \mathrm{~mL}$ suspension) were administered as a single dose on two treatment days separated by a one-week washout period. After dosing, serial blood samples were drawn for a period of 14 hours. Serum harvested from the blood samples was analyzed for the presence of ibuprofen by high-pressure liquid chromatography with ultraviolet detection. Pharmacokinetic parameters were determined from serum concentrations for both formulations. The $90 \%$ confidence intervals of the $\ln$-transformed test/reference treatment ratios for peak plasma concentration and area under the concentration-time curve (AUC) parameters were found to be within the predetermined acceptable interval of $80 \%-125 \%$ set by the US Food and Drug Administration.

Conclusion: Analysis of variance for peak plasma concentrations and AUC parameters showed no significant difference between the two formulations and, therefore, Doloraz was considered bioequivalent to Brufen.

Keywords: ibuprofen, bioequivalence study, pharmacokinetics

\section{Introduction}

Bioequivalence studies are used to compare the expected in vivo biological equivalence of two formulations of a drug. ${ }^{1-4}$ The bioequivalence of two formulations of the same drug can be determined based on the absence of significant differences in primary pharmacokinetic properties of bioavailability, such as the rates of absorption and elimination, ie, peak plasma concentration $\left(\mathrm{C}_{\max }\right)$ and time to peak concentration $\left(\mathrm{T}_{\max }\right)$, and the extent of absorption or total amount of drug absorbed in the body, ie, area under the concentration-time curve (AUC). ${ }^{5}$ Ibuprofen is a propanoic acid derivative (Figure 1), and has the systematic name (RS)-2-(4-(2-methylpropyl) phenyl) propanoic acid, a molecular weight of $206.28 \mathrm{~g} / \mathrm{mol}$, and a molecular formula of $\mathrm{C}_{13} \mathrm{H}_{18} \mathrm{O}_{2}$. Ibuprofen is a chiral molecule, and its two enantiomers are $(R)$-ibuprofen and $(S)$-ibuprofen. In the human body, only $(S)$-ibuprofen is active, and even if prepared and taken as a racemic mixture, an enzyme readily converts $(R)$-ibuprofen to the active $(S)$-ibuprofen form. ${ }^{6,7}$ 


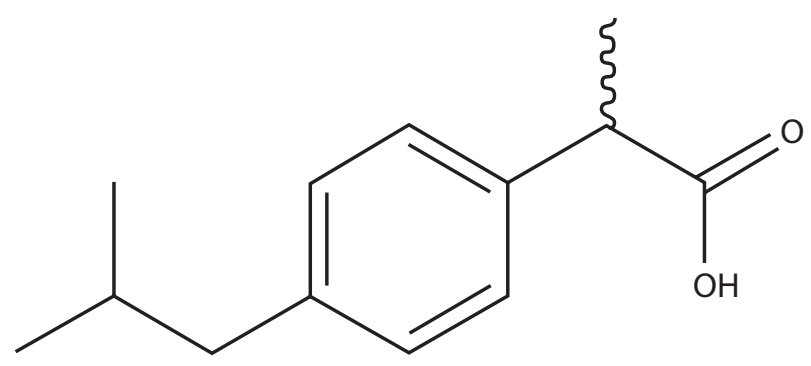

Figure I Chemical structure of (RS)-2-(4-(2-methylpropyl)phenyl)propanoic acid (ibuprofen).

Ibuprofen is considered a nonsteroidal anti-inflammatory drug (NSAID). It is the first member of the propionic acid class of NSAIDs to come into general use. ${ }^{8}$ Ibuprofen has anti-inflammatory, analgesic, and antipyretic activities, and is used for relief of symptoms of arthritis and fever, as an analgesic for pain, especially where there is an inflammatory component, and for dysmenorrhea. ${ }^{9}, 10$ As a cyclooxygenase (COX) inhibitor, it alters platelet function and prolongs bleeding time. ${ }^{10,11}$ The healing properties, side effects, and efficacy of ibuprofen have been studied. ${ }^{12-15}$

Ibuprofen is a nonselective inhibitor of COX-1 and COX-2. This protein enzyme converts certain fatty acids to prostaglandins after a series of chain reactions. Prostaglandins cause increased sensitivity to fever, pain, and increased blood flow or inflammation. Ibuprofen reduces these symptoms and effects by inhibiting the start of this chain of events. ${ }^{16-18}$

Ibuprofen is rapidly absorbed after oral administration, more than (90\%) of an ingested dose is excreted in the urine as metabolites or their conjugates, and the major metabolites are hydroxylated and carboxylated compounds. . $^{11,19,20}$ Peak serum concentrations are reached in 1-2 hours after oral administration. Ibuprofen is rapidly biotransformed, with a serum half-life of about 2 hours. Ibuprofen is extensively bound to plasma proteins, although it occupies only a fraction of the total available drug binding sites at usual concentrations. It passes slowly into the synovial spaces and may remain there in higher concentrations as plasma levels decline. ${ }^{21-23}$

The purpose of this study was to determine the bioequivalence (rate and extent of absorption) of a generic formulation of ibuprofen (Doloraz ${ }^{\circledR} 100 \mathrm{mg}$ suspension, Al-Razi Pharmaceutical Industries Company, Amman, Jordan) in comparison with the reference formulation (Brufen ${ }^{\circledR} 100 \mathrm{mg}$ suspension, Boots Company, Nottingham, UK). The bioequivalence of the formulations was assessed by statistical analysis of pharmacokinetic parameters, as recommended by the US Food and Drug Administration.., 24

\section{Materials and methods Chemicals and reagents}

All solvents were of high-pressure liquid chromatography (HPLC) grade. All other chemicals and reagents were of analytical grade. Acetonitrile and methanol (HPLC grade 99.9\%) were puchased from LabScan, Dublin, Ireland. Acetic acid (analytical grade 99.7\%) was purchased from Scharlau, Barcelona, Spain. Anhydrous sodium acetate (analytical grade, $99.0 \%$ ) was also purchased from Scharlau. Double distilled deionized water for HPLC was purchased from LabScan. Acetone (analytical grade) was purchased from Scharlau. Ibuprofen and indomethacin (internal standard) were obtained from Sigma-Aldrich, St Louis, MO.

\section{Subjects}

Twenty-four healthy male adult volunteers were enrolled in this study, which was performed at Ibn Al-Hytham Hospital, Amman, Jordan. The age range of the subjects was 19-46 years, with a weight range of 53-101 kg and a height range of $164-187 \mathrm{~cm}$. The subjects were instructed to abstain from using any medication for at least 2 weeks prior to and during the study period. ${ }^{5}$ All eligible subjects were informed of the aim and possible risks of this study by the investigators, and then asked to verify their informed consent in writing before participating in the study. The subjects were told that they could withdraw from the study at any time.

\section{Clinical protocol}

The study was conducted in an open-label, randomized, nonreplicated, two-sequence, two-period crossover design with a seven-day washout period between each treatment phase. The study protocol and informed consent form were approved prior to the start of the study by the Institutional Review Board of Ibn Al-Hytham Hospital, Amman, Jordan. The study was conducted in accordance with Good Clinical Practice guidelines and according to the Revised Declaration of Helsinki. ${ }^{25}$ Screening at study start included physical examination, medical history, laboratory safety tests, electrocardiogram, and vital signs. In addition, safety parameters were assessed on treatment days and at follow-up. All patients had to meet carefully selected exclusion/ inclusion criteria determined by the investigators, taking into account their current medical status and life expectancy. Any concomitant disorder not included in the exclusion criteria and any changes in the concomitant disorder and/or medication were documented in the case report forms. All clinical laboratory tests were performed at Ibn Al-Hytham Hospital, Amman, Jordan. 


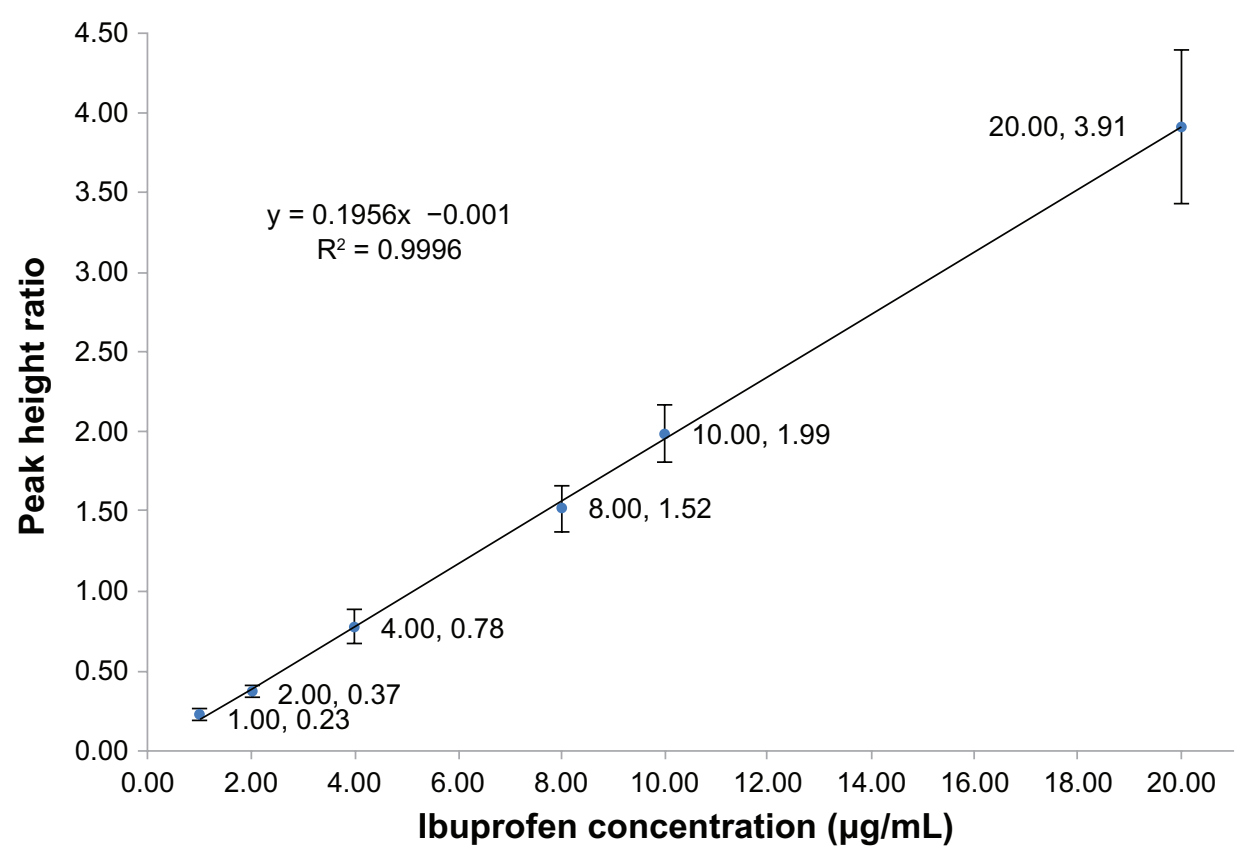

Figure 2 Calibration curve for the mean peak height ratios (from five determinations per concentration level, excluding blank samples) versus ibuprofen concentration ranging from 1.0 to $20.0 \mu \mathrm{g} / \mathrm{mL}(\mathrm{A}-\mathrm{G})$.

Subjects arrived at the hospital 24 hours prior to the beginning of the study. A computer-generated table was used to select and randomly assign the volunteers in a $1: 1$ ratio to the two groups in the study. Doloraz or Brufen suspension $100 \mathrm{mg}$ was taken in period 1 and the alternate formulation was taken in period 2. In each period, at $9 \mathrm{am}$, after an overnight fast of 12 hours and under the supervision of the investigators, subjects were given a single oral dose of one of the formulations (reference or test). An equal number of subjects were assigned to each of the two dosing sequences, in this two-period crossover study design. No subject was alcoholic or a smoker and no alcohol was allowed 24 hours before each study period and until after the last sample in each period had been collected. Volunteers were ambulatory during the study but prohibited from strenuous activity, and were under direct medical supervision at the study site.

Table I Accuracies and precisions for assays of ibuprofen in human serum (six replicates)

\begin{tabular}{llll}
\hline $\begin{array}{l}\text { Theoretical } \\
\text { concentration } \\
\mu \mathrm{g} / \mathrm{mL}\end{array}$ & $\begin{array}{l}\text { Actual } \\
\text { concentration } \\
\mu \mathrm{g} / \mathrm{mL} \text { (mean) }\end{array}$ & Accuracy (\%) & Precision (\%) \\
\hline 1.00 & 1.16 & 115.7 & 16.42 \\
2.00 & 1.90 & 94.86 & 10.73 \\
4.00 & 3.98 & 99.50 & 14.72 \\
8.00 & 7.79 & 97.31 & 9.12 \\
10.00 & 10.17 & 101.7 & 9.01 \\
20.00 & 20.00 & 100.0 & 12.18 \\
\hline
\end{tabular}

\section{Drug administration and sample collection}

Five milliliter suspensions of either the test or reference product were given with $240 \mathrm{~mL}$ of water. Administration of the study medication was supervised by the investigator to ensure that the drug had been swallowed, followed by a mouth check to verify the compliance of the volunteers.

A $10.0 \mathrm{~mL}$ blood sample for the ibuprofen assay were drawn into tubes through an indwelling cannula before and at $0.25,0.5,0.75,1,1.25,1.5,2,3,4,6,8,10,12$, and 14 hours after dosing. The blood samples were centrifuged at $1000 \mathrm{~g}$ for 10 minutes at room temperature $25^{\circ} \mathrm{C} \pm 5^{\circ} \mathrm{C}$. The serum was separated and kept frozen at $-35^{\circ} \mathrm{C}$ in coded polypropylene tubes. After seven days (washout period), the study was repeated in the same manner to complete the crossover design. ${ }^{5}$

\section{Chromatographic conditions}

The HPLC system (GBC-LC) used was an isocratic system consisting of an HPLC pump (GBC-LC 1150), a GBC-LC 1210 ultraviolet-visible variable wavelength detector, an HP-3395 integrator, and a manual injector (Rheodyne, Rohnert Park, CA). Separation was carried out on a stainless steel $\mathrm{C}_{18}$, Luna ${ }^{\circledR} 5 \mu \mathrm{m} \mathrm{C}_{18}$ (2) $100 \AA$ new column $(150 \times 4.0 \mathrm{~mm}$, Phenomenex, Torrance, CA $)$, with a Waters Symmetry $\mathrm{C}_{18} 5 \mu \mathrm{m} 3.9 \times 20 \mathrm{~mm}$ precolumn guard column (Waters, Milford, MA). The mobile phase consisted of acetonitrile, in acetate buffer at $\mathrm{pH}$ 4.9. The mobile phase was filtered through a $0.22 \mu \mathrm{m}$ membrane filter, degassed using 
Table 2 Analysis of quality control samples in six replicates from an equivalent serum sample at three concentrations representing the entire range of the standard curve (indomethacin concentration was $3.0 \mu \mathrm{g} / \mathrm{mL}$ )

\begin{tabular}{|c|c|c|c|c|c|c|c|c|}
\hline \multicolumn{9}{|c|}{ Ibuprofen $1.0 \mu \mathrm{g} / \mathrm{mL}$ and indomethacin $3.0 \mu \mathrm{g} / \mathrm{mL}$} \\
\hline $\mathrm{PH}$ ratio I & $\mathrm{PH}$ ratio 2 & $\mathrm{PH}$ ratio 3 & $\mathrm{PH}$ ratio 4 & $\mathrm{PH}$ ratio 5 & $\mathrm{PH}$ ratio 6 & Mean & CV (\%) & $\operatorname{RE}(\%)$ \\
\hline 0.1875 & 0.1746 & 0.1744 & 0.1711 & 0.2000 & 0.1944 & 0.1836 & 7.26 & 94.02 \\
\hline \multicolumn{9}{|c|}{ Ibuprofen $4.0 \mu \mathrm{g} / \mathrm{mL}$ and indomethacin $3.0 \mu \mathrm{g} / \mathrm{mL}$} \\
\hline $\mathrm{PH}$ ratio I & $\mathrm{PH}$ ratio 2 & $\mathrm{PH}$ ratio 3 & $\mathrm{PH}$ ratio 4 & $\mathrm{PH}$ ratio 5 & $\mathrm{PH}$ ratio 6 & Mean & $\pm \mathrm{SD}$ & $\operatorname{RE}(\%)$ \\
\hline 0.7230 & 0.720 & 0.7078 & 0.7340 & 0.6896 & 0.7241 & 0.7164 & 2.39 & 91.53 \\
\hline \multicolumn{9}{|c|}{ Ibuprofen $10.0 \mu \mathrm{g} / \mathrm{mL}$ and indomethacin $3.0 \mu \mathrm{g} / \mathrm{mL}$} \\
\hline $\mathrm{PH}$ ratio $\mathrm{I}$ & $\mathrm{PH}$ ratio 2 & $\mathrm{PH}$ ratio 3 & $\mathrm{PH}$ ratio 4 & $\mathrm{PH}$ ratio 5 & $\mathrm{PH}$ ratio 6 & Mean & $\pm \mathrm{SD}$ & $\operatorname{RE}(\%)$ \\
\hline $1.828 \mid$ & 1.6976 & 1.7307 & 1.8823 & 1.8500 & 1.7500 & 1.7897 & 4.48 & 91.16 \\
\hline
\end{tabular}

Abbreviations: $\mathrm{PH}$, peak height; $\mathrm{CV}$, coefficient of variation; SD, standard deviation; RE, relative error.

ultrasonication before use and was pumped at a flow rate of $0.8 \mathrm{~mL} / \mathrm{min}$. The column temperature was $25^{\circ} \mathrm{C}$ under these conditions. The effluent was monitored using an ultraviolet detector with an excitation wavelength of $220 \mathrm{~nm} \cdot{ }^{26-28}$

\section{Sample preparation for HPLC injection}

Serum samples were analyzed for ibuprofen and the internal standard according to a precise and accurate HPLC method and validated according to international guidelines. ${ }^{24,29} \mathrm{~A} 0.2 \mathrm{~mL}$ of the sample and $0.2 \mathrm{~mL}$ of the internal standard (indomethacin, $3.0 \mu \mathrm{g} / \mathrm{mL}$ ) were transferred to a $10.0 \mathrm{~mL}$ teflon-screw capped test tube, and vortex-mixed for approximately 15 seconds. Methanol solvent $0.5 \mathrm{~mL}$ was then added and mixed. The mixture was centrifuged and the upper organic layer was separated and evaporated under a stream of nitrogen to dryness. ${ }^{27,28}$ The residue was reconstituted with $0.1 \mathrm{~mL}$ of mobile phase, and 15.0 $\mu \mathrm{L}$ was injected into the HPLC column.

\section{Pharmacokinetic analysis}

All values below the limit of quantification were considered as zero for the computation of pharmacokinetic parameters and statistical calculations. Pharmacokinetic parameters

Table 3 Summary of stability data related to short and prolonged storage conditions $\left(\right.$ at $-35^{\circ} \mathrm{C}$ ) of ibuprofen expressed as recovery (\%)

\begin{tabular}{ll}
\hline Days & Analytical ibuprofen concentration $10.0 \mu \mathrm{g} / \mathrm{mL}$ \\
\cline { 2 - 2 } & Recovery $(\%)$ \\
\hline 1 & 104.41 \\
3 & 97.82 \\
6 & 100.55 \\
12 & 100.85 \\
24 & 100.03 \\
48 & 99.75 \\
Mean & 100.73 \\
SD & 2.30 \\
CV\% & 2.29 \\
\hline
\end{tabular}

Abbreviations: SD, standard deviation; CV, coefficient of variation. were determined and calculated using a WinNonMix version 2.0.1 computer program. The elimination rate constant $\left(\mathrm{K}_{\mathrm{e}}\right)$ was obtained from the least-square fitted terminal loglinear portion of the serum concentration-time profile. The ibuprofen $\mathrm{C}_{\max }$ and the corresponding $\mathrm{T}_{\max }$ were determined by the individual drug serum concentration-time profiles. The elimination half-life $\left(\mathrm{T}_{1 / 2}\right)$ was calculated as $0.693 / \mathrm{K}_{\mathrm{e}}$. The area under the curve to the last measurable concentration $\left(\mathrm{AUC}_{0-t}\right)$ was calculated by the linear trapezoidal rule. The area under the curve extrapolated to infinity $\left(\mathrm{AUC}_{0-\infty}\right)$ was calculated as $\mathrm{AUC}_{0-\mathrm{t}}+\mathrm{C}_{\mathrm{t}} / \mathrm{K}_{\mathrm{e}}$, where $\mathrm{C}_{\mathrm{t}}$ was the last measurable concentration. ${ }^{30}$

\section{Statistical analysis}

The primary pharmacokinetic parameters used in the bioequivalence analysis were $\mathrm{AUC}_{0-\infty}, \mathrm{AUC}_{0-t}$, and $\mathrm{C}_{\max }$. Bioequivalence was assessed by means of an analysis of variance of the crossover design and estimating $90 \%$ confidence intervals (CI) for the ratio of the means of the test/reference products using log-transformed data. ${ }^{5}$

\section{Results and discussion Assay validation}

In the procedure described below, a calibration curve and quality control processes were utilized. Endogenous compound interferences were assessed by analyzing drug-free

Table 4 Summary of stability data of ibuprofen under freezethaw conditions expressed as recovery (\%)

\begin{tabular}{lll}
\hline & \multicolumn{2}{l}{ Ibuprofen concentration $(\mu \mathrm{g} / \mathrm{mL})$} \\
\cline { 2 - 3 } & $\begin{array}{l}\mathbf{4 . 0} \mu \mathrm{g} / \mathrm{mL}(\%) \\
\text { recovery }\end{array}$ & $\begin{array}{l}\mathbf{8 . 0} \mu \mathrm{g} / \mathrm{mL}(\%) \\
\text { recovery }\end{array}$ \\
\hline Zero time $(\mathrm{n}=3)$ & 102.77 & 101.09 \\
Cycle I $(\mathrm{n}=3)$ & 102.33 & 99.27 \\
Cycle 2 $(\mathrm{n}=3)$ & 99.96 & 100.94 \\
Cycle 3 $(\mathrm{n}=3)$ & 103.05 & 101.10 \\
\hline
\end{tabular}


serum, serum spiked with ibuprofen, and serum obtained from subjects given ibuprofen.

The matrix-based calibration curves were analyzed in duplicate in each analytical run. Each standard curve was defined by six standard points excluding the blank sample, covering the entire range of concentrations between 1.0 (the acceptable lower limit of quantification was found to be $1.0 \mu \mathrm{g} / \mathrm{mL}$ ) to $20.0 \mu \mathrm{g} / \mathrm{mL}$ (Figure 2). To validate the bioanalytical method, accuracy and precision were determined using six determinations per concentration level, excluding the blank sample (Table 1). Accuracy and precision were also demonstrated for the known concentration of ibuprofen in the biological matrix, quality control samples at the low, middle, and near upper level of the standard curve were accomplished (Table 2).

Long-term stability (Table 3) and freeze-thaw stability tests for ibuprofen expressed as recovery (Table 4) in the biological matrix were established.

The linearity of the calibration curve for ibuprofen was assessed in the range of $1.0-20.0 \mu \mathrm{g} / \mathrm{mL}$ in $0.2 \mathrm{~mL}$ serum. A $0.2 \mathrm{~mL}$ aliquot of the internal standard $(3.0 \mu \mathrm{g} / \mathrm{mL}$ of indomethacin) prepared in double distilled water was then added. The mean regression equation from six replicated assays was as follows:
$\mathrm{Y}=0.1956 \mathrm{x}-0.001, \mathrm{R}^{2}=0.9996$. Linear regression analysis was used to calculate the concentrations of ibuprofen in the serum samples. The relative standard deviation of the assay and the relative errors of the mean were used to validate the precision and accuracy of the assay through identification of standard samples of ibuprofen in serum. The percentage peak height ratios of the analyte to the internal standard were used to assess the absolute recoveries of ibuprofen extracted from the serum samples.

\section{Proof of applicability}

To verify the quality control process, the standard curve was used with each set of samples. The ratios obtained from the extracted quality control samples were compared with those resulting from direct injection of the prepared ibuprofen working standard in the mobile phase and the internal standard (indomethacin $3.0 \mu \mathrm{g} / \mathrm{mL}$ ). Three quality control samples containing $1.0 \mu \mathrm{g} / \mathrm{mL}, 4.0 \mu \mathrm{g} / \mathrm{mL}$, and $10.0 \mu \mathrm{g} / \mathrm{mL}$ concentrations of the working standard were used to check precision and accuracy (Table 2).

To test for specificity, different samples of control human serum were analyzed with and without ibuprofen and internal standard, to determine whether any endogenous serum

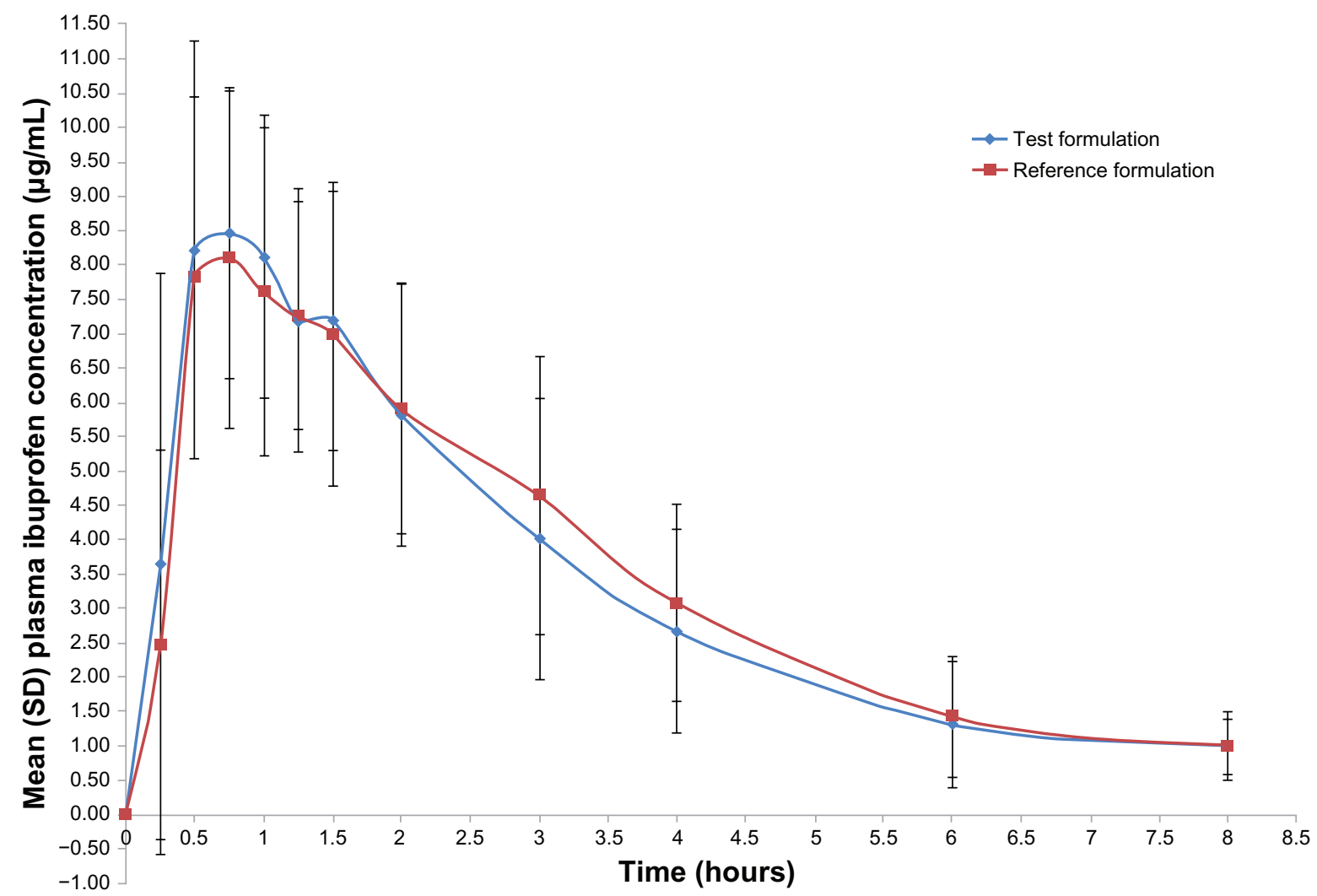

Figure 3 Serum concentration-time plots for $100 \mathrm{mg}$ of ibuprofen after a single oral dose of the test and reference formulations in healthy adult male volunteers $(\mathrm{n}=24)$ The lower limit of quantitation was $1.0 \mu \mathrm{g} / \mathrm{mL}$. 
Table 5 Pharmacokinetic parameters over eight hours with two formulations, Brufen ${ }^{\circledR}$ (reference) and Dolaraz ${ }^{\circledR}$ (test) after a single oral dose of $100 \mathrm{mg}$ formulation in 24 healthy adult male volunteers

\begin{tabular}{lll}
\hline Parameter & $\begin{array}{l}\text { Reference mean } \\
( \pm \text { SD) }\end{array}$ & $\begin{array}{l}\text { Test } \\
\text { (Mean } \pm \text { SD) }\end{array}$ \\
\hline $\mathrm{AUC}_{0-\infty} \mu \mathrm{g} / \mathrm{mL} / \mathrm{hour}$ & $31.79(10.60)$ & $29.69(9.79)$ \\
$\mathrm{AUC}_{0-\mathrm{t}} \mu \mathrm{g} / \mathrm{mL} /$ hour & $28.17(8.12)$ & $27.21(9.01)$ \\
$\mathrm{C}_{\max } \mu g / \mathrm{mL}$ & $9.92(2.13)$ & $10.05(1.84)$ \\
$\mathrm{T}_{\max }$, hours & $0.80(0.42)$ & $0.90(0.58)$ \\
$\mathrm{K}_{\mathrm{e}}$ & $0.31(0.22)$ & $0.36(0.23)$ \\
$\mathrm{T}_{1 / 2}$, hours & $2.98(1.37)$ & $2.44(1.19)$ \\
\hline
\end{tabular}

Abbreviations: $A \cup C_{0-\infty}$, area under the curve extrapolated to infinity; $A \cup C_{0-\tau}$, area under the curve to the last measurable concentration; $C_{\text {max }}$, peak plasma concentration; $T_{\text {max }}$, time to peak concentration; $T_{1 / 2}$, elimination half-life; $\mathrm{K}_{\mathrm{e}}$, elimination rate constant.

constituents interfered with the analyte or the internal standard. No significant interfering peaks from the serum were found at the retention times of ibuprofen and the internal standard, indomethacin.

A stability test was designed to detect possible degradation of ibuprofen in the serum samples during sampling, sample preparation, analysis processes and storage. Two types of stability studies were carried out, ie, stability under freeze-thaw conditions and under long-term storage. For the stability under freeze-thaw conditions, three freeze-thaw cycles were investigated using spiked serum with ibuprofen concentrations of $4.0 \mu \mathrm{g} / \mathrm{mL}$ and $8.0 \mu \mathrm{g} / \mathrm{mL}$. The results are summarized in Table 4 and show no significant differences. For long-term storage, ibuprofen was subjected to prolonged storage conditions $\left(-35^{\circ} \mathrm{C}\right)$ during the study period. No significant differences were found (Table 3 ). The mean recoveries were determined at $1.0 \mu \mathrm{g} / \mathrm{mL}$ and $4.0 \mu \mathrm{g} / \mathrm{mL}$ in six replicates and were found to be $89.5 \pm 9.1 \mu \mathrm{g} / \mathrm{mL}$ and $91.8 \pm 5.8 \mu \mathrm{g} / \mathrm{mL}$ (mean \pm standard deviation), respectively.

\section{Pharmacokinetic properties}

Both formulations were readily absorbed and ibuprofen was measurable at the first sampling time ( 0.25 hours $)$ in all volunteers. The mean concentration-time curves of the two ibuprofen formulations were similar, as depicted in Figure 3. The mean ibuprofen $\mathrm{C}_{\text {max }}$ of the reference and test formulations was $9.92 \pm 2.13 \mu \mathrm{g} / \mathrm{mL}$ and $10.05 \pm 1.84 \mu \mathrm{g} / \mathrm{mL}$, respectively (Table 5). The $\mathrm{T}_{\max }$ of the reference and test formulations was $0.80 \pm 0.42$ hours and $0.90 \pm 0.58$ hours. The $T_{1 / 2}$ of the reference and test formulations was $1.73 \pm 1.00$ hours and $1.68 \pm 1.30$ hours. The $\mathrm{AUC}_{0-\mathrm{t}}$ mean of the reference and test formulations were $30.34 \pm 9.72 \mu \mathrm{g} / \mathrm{mL} / \mathrm{hour}$ and $29.78 \pm 11.33 \mu \mathrm{g} / \mathrm{mL} /$ hour.
Table 6 Statistical results and ratios of means of test and reference products and $90 \%$ confidence intervals

\begin{tabular}{lllll}
\hline $\begin{array}{l}\text { Pharmacokinetic }_{\text {parameters }} \\
\text { poloraz }\end{array}$ & $\begin{array}{l}\text { Dean }^{\circledR} \\
\text { meufen }\end{array}$ & $\begin{array}{l}\text { Rean } \\
\text { meatio of }\end{array}$ & $\begin{array}{l}\mathbf{9 0 \%} \mathbf{C l} \\
\text { means }\end{array}$ & \\
\hline LnAUC $_{0-\infty}$ & 3.34 & $3.4 \mathrm{I}$ & 0.981 & $0.807-1.092$ \\
$\mathrm{LnAUC}_{0-\mathrm{t}}$ & 3.26 & 3.30 & 0.987 & $0.838-1.098$ \\
$\mathrm{LnC}_{\max }$ & 2.29 & 2.27 & 1.009 & $0.914-1.138$ \\
\hline
\end{tabular}

Abbreviations: $A \cup C_{0-\infty}$, area under the curve extrapolated to infinity; $A \cup C_{0-1,}$ area under the curve to the last measurable concentration; $\mathrm{Cl}$, confidence interval; Cmax, the peak plasma concentration.

\section{Bioequivalence criteria}

To make a bioequivalence evaluation on the basis of the mean serum levels of the 24 volunteers completing the study, various statistical modules were applied to $\mathrm{AUC}_{0-\infty}$, $\mathrm{AUC}_{0-\mathrm{t}}$, and $\mathrm{C}_{\max }$ as per current US Food and Drug Administration guidelines. ${ }^{24}$ Table 6 shows the $90 \%$ confidence intervals of the ratios (test-reference) for the ln-transformed values of $\mathrm{C}_{\max }$ (index of the rate of absorption), $\mathrm{AUC}_{0-\mathrm{t}}$, and $\mathrm{AUC}_{0-\infty}$ (indices of the extent of absorption). The $90 \%$ confidence intervals for the corresponding ratios of $\mathrm{C}_{\max }$, $\mathrm{AUC}_{0-\mathrm{t}}$, and $\mathrm{AUC}_{0-\infty}$ were $91.4 \%-113.8 \%, 83.4 \%-112.5 \%$, and $83.0 \%-112.6 \%$, respectively, meeting the criteria for bioequivalence.

\section{Tolerability}

In this study, ibuprofen was well tolerated by the volunteers. No incident that could have influenced the outcome of the study was reported. No clinical significant adverse events were reported. All volunteers who started the study continued to the end and were discharged in good health.

\section{Conclusion}

The difference between each of the respective primary parameters for test and reference products was found to be statistically nonsignificant for each active ingredient $(P<0.05$ for the probability of exceeding the limits of acceptance). The $90 \%$ confidence intervals for the test/reference ratios of these parameters were found to be within the acceptable range of $80 \%-125 \%$ for bioequivalence, as established by the US Food and Drug Administration. The pharmacokinetic results showed no statistically significant differences in $\mathrm{C}_{\text {max }}$ or AUC between the generic and branded formulations of $100 \mathrm{mg}$ formulations of ibuprofen. Based on the regulatory requirements and criteria for bioequivalence, these two formulations were considered bioequivalent. Both formulations were well tolerated.

\section{Disclosure}

The authors report no conflicts of interest in this work. 


\section{References}

1. Chen ML, Shah V, Patnaik R, et al. Bioavailability and bioequivalence: an FDA regulatory overview. Pharm Res. 2001;18:1645-1650.

2. Lee JY, Kim BC, Park SG. Average bioequivalence for two-sequence two-period crossover design with incomplete data. J Biopharm Stats. 2005;15:857-867.

3. Rani S, Pargal A. Bioequivalence: An overview of statistical concepts. Indian J Pharmacol. 2004;36:209-216.

4. Al-Talla ZA, Akrawi SH, Emwas AHM. Solid state NMR and bioequivalence comparison of the pharmacokinetic parameters of two formulations of clindamycin. Int J Clin Pharmacol Ther. 2011;49:469-476.

5. US Food and Drug Administration. Guidance for industry bioavailability and bioequivalence studies for orally administered drug products. In: US Department of Health and Human Services, Center for Drug Evaluation and Research, editors. Rockville, MD: US Food and Drug Administration; 2003.

6. Lee E, Williams K, Day R, Graham G, Champion D. Stereoselective disposition of ibuprofen enantiomers in man. Br J Clin Pharmacol. 2004;58:S759-S764.

7. Evans AM, Nation RL, Sansom LN, Bochner F, Somogyi AA. Stereoselective plasma protein binding of ibuprofen enantiomers. Eur J Clin Pharmacol. 1989;36:283-290.

8. Brunton L, Chabner B, Knollman B. Goodman and Gilman's The Pharmacological Basis of Therapeutics. 12th ed. New York, NY: McGraw-Hill; 2010.

9. Hersh E, Moore P, Ross G. Over-the-counter analgesics and antipyretics: a critical assessment. Clin Ther. 2000;22:500-548.

10. Department of Health. The British Pharmacopoeia. 99th ed. London, UK: Stationery Office Books; 1999.

11. Brunton L, Lazo J, Parker K. Goodman and Gilman's The Pharmacological Basis of Therapeutics. New York, NY: McGraw Hill; 2005.

12. Jorgensen B, Friis GJ, Gottrup F. Pain and quality of life for patients with venous leg ulcers: proof of concept of the efficacy of Biatain (R)-Ibu, a new pain reducing wound dressing. Wound Repair Regen. 2006;14:233-239.

13. Rasenack N, Müller B. Properties of ibuprofen crystallized under various conditions: A comparative study. Drug Dev Ind Pharm. 2002;28:1077-1089.

14. Southworth S, Peters J, Rock A, Pavliv L. A multicenter, randomized, double-blind, placebo-controlled trial of intravenous ibuprofen 400 and $800 \mathrm{mg}$ every 6 hours in the management of postoperative pain. Clin Ther. 2009;31:1922-1935.

15. Dong YL, Fleming R, Yan TZ, Herndon DN, Waymack JP. Effect of ibuprofen on the inflammatory response to surgical wounds. JTrauma. $1993 ; 35: 340$.
16. Mitchell JA, Akarasereenont P, Thiemermann C, Flower RJ, Vane JR. Selectivity of nonsteroidal antiinflammatory drugs as inhibitors of constitutive and inducible cyclooxygenase. Proc Natl Acad Sci U S A. 1993;90:11693.

17. Vane J. The mechanism of action of anti-inflammatory drugs. Int J Clin Pract. 2003;2:2.

18. Tegeder I, Pfeilschifter J, Geisslinger G. Cyclooxygenase-independent actions of cyclooxygenase inhibitors. FASEB J. 2001;15:2057.

19. Heyman E, Morag I, Batash D, Keidar R, Baram S, Berkovitch M. Closure of patent ductus arteriosus with oral ibuprofen suspension in premature newborns: a pilot study. Neoreviews. 2003;11:e354.

20. Olive G. Analgesic/antipyretic treatment: ibuprofen or acetaminophen? An update. Therapie. 2006;61:151-160. French.

21. Antal E, Wright C, Brown B, Albert K, Aman L, Levin N. The influence of hemodialysis on the pharmacokinetics of ibuprofen and its major metabolites. J Clin Pharmacol. 1986;26:184.

22. Tripathi KD. Essentials of Medical Pharmacology. 5th ed. New Delhi, India: Jaypee Brothers Medical Publishers; 2004.

23. Gallo J, Gall E, Gillespie W, Albert K, Perrier D. Ibuprofen kinetics in plasma and synovial fluid of arthritic patients. J Clin Pharmacol. 1986;26:65.

24. US Food and Drug Administration. Guidance for Industry Statistical Approaches to Establishing Bioequivalence. In: US Department of Health and Human Services, Center for Drug Evaluation and Research, editors. Rockville, MD: US Food and Drug Administration; 2001.

25. World Medical Association. WMA Declaration of Helsinki Ethical Principles for Medical Research Involving Human Subjects. 53rd ed. Washington, DC: World Medical Association; 2002.

26. Haikala VE, Heimonen IK, Vuorela HJ. Determination of ibuprofen in ointments by reversed-phase liquid-chromatography. J Pharm Sci. 1991;80:456-458.

27. Lalande M, Wilson DL, McGilveray IJ. Rapid high-performance liquid-chromatographic determination of ibuprofen in human-plasma. J Chromatogr. 1986;377:410-414.

28. Sochor J, Klimes J, Zahradnícek M, Sedlácek J. High-performance liquid chromatographic assay for ibuprofen in whole blood using solidphase extraction. J Chromatogr B Biomed Appl. 1994;654:282-286.

29. Dadgar D, Burnett PE, Choc MG, Gallicano K, Hooper JW. Application issues in bioanalytical method validation, sample analysis and data reporting. J Pharm Biomed Anal. 1995;13:89-97.

30. Walker R, Edwards C. Clinical Pharmacy and Therapeutics. Edinburgh, UK: Churchill Livingstone; 2003.

\section{Publish your work in this journal}

Drug Design, Development and Therapy is an international, peerreviewed open-access journal that spans the spectrum of drug design and development through to clinical applications. Clinical outcomes, patient safety, and programs for the development and effective, safe, and sustained use of medicines are a feature of the journal, which

\section{Dovepress}

has also been accepted for indexing on PubMed Central. The manuscript management system is completely online and includes a very quick and fair peer-review system, which is all easy to use. Visit http://www.dovepress.com/testimonials.php to read real quotes from published authors. 